\title{
LARVAL SUSCEPTIBILITY OF AEDES AEGYPTI (L.) (DIPTERA: CULICIDAE) TO EXTRACTS OF ILEX PARAGUARIENSIS AND ILEX THEEZANS \\ SUSCETIBILIDADE LARVAL DE AEDES AEGYPTI (L.) (DIPTERA: CULICIDAE) AOS EXTRATOS DE ILEX PARAGUARIENSIS E ILEX THEEZANS
}

\section{Ana Carla Knakiewicz \\ Biological Science Student, Community University of Chapecó Region \\ (Unochapeco) - Chapecó (SC), Brazil. \\ Junir Antonio Lutinski \\ Ph.D. in Animal Biodiversity. Professor of the Graduate Program in Health Science, Community University of Chapecó Region (Unochapeco) - Chapecó (SC), Brazil.}

\section{Carin Guarda}

Graduation in Biological Science, Master degree student in Health Science, Community University of Chapecó Region(Unochapeco) Chapecó (SC), Brazil.

\section{Ariane Paris}

Biological Science Student, Community University of Chapecó Region (Unochapeco) - Chapecó (SC), Brazil.

\section{Alencar Belotti}

Agronomist, Community University of Chapecó Region (Unochapeco) Chapecó (SC), Brazil.

\section{Maria Assunta Busato}

Ph.D. in Biology. Professor of the Graduate Program in Health Science, Community University of Chapecó Region (Unochapeco) - Chapecó (SC), Brazil.

\section{Walter Antonio Roman Junior}

Ph.D. in Pharmaceutical Sciences. Professor of the Graduate Program in Health Science, Community University of Chapecó Region (Unochapeco) Chapecó (SC), Brazil.

\section{Daniel Albeny Simões}

Ph.D. in Entomology. Professor of the Graduate Program in Environmental Sciences, Community University of Chapecó Region (Unochapeco) Chapecó (SC), Brazil.

\section{Corresponding address:}

Junir Antonio Lutinski-Rua Beija-Flor, 254 E, Efapi, 89809-760 - Chapecó (SC), Brasil-E-mail: junir@unochapeco.edu.br

\section{ABSTRACT}

Aedes aegypti is the main vector of dengue, Chikungunya and Zika virus worldwide. The strategies for the population control involve the use of synthetic insecticides, which may cause toxicity problems and environmental contamination. This study evaluated the larvicide effect of hydroalcoholic extracts of leaves and fruits llex paraguariensis and llex theezans on A. aegypti. The bioassays were conducted under controlled conditions. Fresh and dry fruits of $I$. paraguariensis showed the higher larvicidal activity on A. aegypti than the leaves of the same species. Mosquito larvae showed increased susceptibility from dried leaf extracts, fresh fruit and leaf of I. theezans. It was also observed a variation in larval mortality during periods of exposure. The larvicide efficiency of $I$. theezans extracts on $A$. aegypti are promising results and widen the possibility for further studies of the use of extracts of this plant.

Keywords: vector control; dengue; yerba mate; larvicide; natural products.

\section{RESUMO}

Aedes aegypti é o principal vetor da dengue, febre Chikungunya e Zika vírus em escala global. As estratégias para controle populacional deste vetor recorrem à utilização de inseticidas sintéticos, que podem acarretar problemas de intoxicação e contaminação ambiental. Este estudo avaliou o efeito larvicida de extratos hidroalcoólicos de folhas e frutos de Ilex paraguariensis e de llex theezans sobre $A$. aegypti. Os bioensaios foram conduzidos sob condições controladas. Os frutos in natura e secos de I. paraguariensis demonstraram maior atividade larvicida sobre A. aegypti em relação às folhas da mesma espécie. As larvas do mosquito demonstraram maior susceptibilidade frente aos extratos de folhas secas, in natura e frutos verdes de $I$. theezans. Também foi observada variação na mortalidade larval nos períodos de exposição. A eficiência larvicida dos extratos de 1 . theezans são resultados promissores e abrem a possibilidade para estudos subsequentes do uso de extratos desta planta.

Palavras-chave: controle vetorial; dengue; erva-mate; larvicida; produtos naturais. 


\section{INTRODUCTION}

The epidemiological situation of dengue, Chikungunya fever and Zika virus in Brazil has been increasingly complex as its main vector. The mosquito Aedes aegypti (Linnaeus 1762) is spread by almost all the national territory, where epidemics have been recurrent (BARRETO \& TEIXEIRA, 2008). The $A$. aegypti is one of more than 500 species of the Aedes genus (Diptera: Culicidae), considered as the main vector of these viruses and also of urban Yellow Fever. It uses water tanks to lay its eggs and consequently develop their larvae. An important evolutionary feature that allowed the conquest of a large proportion of the globe is that its eggs are resistant to desiccation, remaining viable in the absence of water for more than one year (TAUIL, 2002; POWELL \& TABACHNICK, 2013). When it is in contact with water, the larvae emerges, going through four stages (L1, L2, L3 and L4) and subsequently originating the pupae and, soon after, adult mosquitoes (NEVES, 2011).

Among the strategies for population control of this vector, there is also the use of synthetic insecticides, such as Pyrethroids Deltamethrin and the Carbamate Bendiocarb (GUARDA et al., 2016). The use of these insecticides may cause toxicity problems and environmental contamination, leading to risks to local biodiversity and human health. Synthetic insecticides have low selectivity and can select genes that cause resistance in populations of Aedes (CALDAS, 2000; SANTIAGO et al., 2005). The vector management with the use of natural products is less intrusive than using the conventional insecticides (synthetic), having a more rapid degradation, resulting in lower occupational exposure and less environmental pollution (VALLADARES; DEFAGO; PALACIOS, 1997; BARRETO, 2005).

Studies have shown the effectiveness of natural products for the control of embryonic development, larval, pupa and adult emergence of $A$. aegypti (BRUNHEROT-
TO \& VENDRAMIM, 2001; ROSSI et al., 2007; BUSATO et al., 2015). A perspective arises from the study of Busato et al. (2015) successfully testing the larvicide efficiency to the ethanol extracts of leaves of Ilex paraguariensis A. St.-Hill (Aquifoliaceae) on A. aegypti.

The species I. paraguariensis is from South America, popularly known as yerba mate or congonha, being grown and consumed as tea or mate in Argentina, Brazil, Paraguay, and Uruguay. After processing, its leaves and branches make the drinks appreciated by the population of these countries (SOUZA, 2009; LORENZI \& MATOS, 2002). In the botanical description of Kricun (1983) and Giberti (1995), it is an evergreen tree, with height about 3 to $5 \mathrm{~m}$ (in growing forests) and up to $12 \mathrm{~m}$ high and $70 \mathrm{~cm}$ in diameter, in a native forest environment. Besides its cultural and gastronomic aspects, the great commercial interest in I. paraguariensis is due to the presence of caffeine and theobromine, recognized for exercising stimulating effects on cardio-circulatory systems as coffee, cocoa and guarana (CASTALDELLI et al., 2011). The plant also has vitamins, amino acids and triterpene saponins of nutritional and medicinal interest in its chemical constitution (RATES, 2004; PIOVEZAN-BORGES et al., 2016).

The llex theezans Mart species Ex Reissek (Aquifoliaceae) is popularly known as Cauna and little used commercially, but common in vegetation types in the South of Brazil. It is an evergreen tree, early secondary or late secondary species. Its height reaches up to $20 \mathrm{~m}$, has a diameter of $70 \mathrm{~cm}$ and the chemical properties of the extracts of this plant are still poorly known.

In this context, this study aimed to evaluate the larvicidal effect of hydroalcoholic extracts of leaves and greens and dried fruit of I. paraguariensis, native and cultivated and $I$. theezans on $A$. aegypti.

\section{MATERIAL AND METHODS}

\section{Plant material}

The leaves and fruits collection of I. paraguariensis, native and cultivated and $I$. theezans were held in Marechal Bormann district $\left(27^{\circ}, 19^{\prime} 05^{\prime \prime} \mathrm{S}, 52^{\circ}, 65^{\prime} 11^{\prime \prime} \mathrm{W}\right)$,
Chapecó (SC), on December 2015. The collected plant material was identified by the curator of the Herbarium of the Universidade Comunitária da Região de Chapecó. 
These materials were transferred to the Pharmacognosy Laboratory, reduced to small fragments, and submitted to drying at room temperature, protected from direct light and moisture. Subse-

\section{Extracts production}

For the preparation of extracts by turbolisis (5 days), fresh and dried leaves and fruits, were follow protocol used as recommended by the Brazilian Pharmacopoeia (FB 5, 2010). There were 12 extracts prepared: fresh and dry leaves, as well as the fruits of $I$. paraguariensis (na-

\section{Experimental procedure}

The collection of eggs of $A$. aegypti was conducted from November 2015 to April 2016. There were 15 egg-traps characterized as plastic containers of black color, with a capacity of $500 \mathrm{~mL}$, with $200 \mathrm{~mL}$ of water into each trap and monitored every 7 days. For laying the eggs and for the collection of the field, a white crop seed germination paper cut into strips of $29.7 \times 10 \mathrm{~cm}$ was used (GOMES; SCIARICO; EIRAS, 2006). The cut was placed around the inside of the trap so that approximately four centimeters were submerged in the solution. The egg traps were distributed at different points of the city of Chapecó, in establishments previously known by the

\section{Experimental design}

The experimental microcosms were in transparent plastic cups with $300 \mathrm{~mL}$ capacity. Each microcosm had a volume of $80 \mathrm{~mL}$ of vegetable extracts concentrations ranging from 500 to 2,000 Experimental $\mathrm{g} / \mathrm{mL}$ and 20 active $A$. aegypti larvae of the second stage. The control microcosms received only $80 \mathrm{~mL}$ of untreated water and 20 mosquito larvae. Each treatment

\section{Statistical analysis}

The data evaluation was performed by the analysis of variance (ANOVA, one-way) on the number of living larvae, where the means were grouped by the Duncan test at $5 \%$ probability of error. The efficiency of the treatments tested was calculated by Abbott equation quently, the dried plants were ground in a knife mill (Ciemlab ${ }^{\circ}$, CE430) selected in a filter of $425 \mu \mathrm{m}$ (35 Tyler/Mesh), identified and stored away from the light.

tive and cultivated); leaves (fresh and dried) and fruit of I. theezans. After their filtration through Büchner funnel, the extracts were concentrated by rotary evaporation under reduced pressure, lyophilized, weighed and stored in a freezer at $-20^{\circ} \mathrm{C}$ for further assays.

mosquito infestation, according to data from the Programa Municipal de Controle da Dengue (city program for dengue control).

The papers with the eggs were placed in white plastic trays $20 \times 30 \mathrm{~cm}$ containing $2 \mathrm{~L}$ of water without treatment to obtain the larvae. The larvae were fed with fish feed (Holiday ${ }^{\circ}$ ) and remained in the trays until the $L 2$ stage with a period of three days. The bioassays were carried out in laboratory conditions (Ecological Entomology Laboratory - LABENT-Eco of the Community University of Chapecó Region), with a temperature of $28 \pm 3^{\circ} \mathrm{C}$ and a photoperiod of 12 hours.

was repeated three times and all larvae used in the experiment were fed with fish feed - only at the beginning of the test. Larval susceptibility was evaluated at intervals of 24,48 and $72 \mathrm{~h}$ after exposure to the solutions. The living larvae were counted in each period. After the experiment ends, the remaining larvae were sacrificed in boiling water and discarded.

(1925), used to compare the treatments with respect to control and defined by the formula \%Efficiency = $(T-t) * 100 / T$, where " $T$ " represents the average number of living larvae in Control, and " $\mathrm{t}$ " is the average of surviving larvae in each treatment.

\section{RESULTS}

Larval susceptibility to $A$. aegypti was significantly affected by the treatment variable, by the time variable and also by the interaction between treatment and time (Table 1). 
The extracts of dried leaves of $I$. theezans at a concentration of $750 \mu \mathrm{g} / \mathrm{mL}$ showed the highest larvicide efficiency from the first 24 hours. There was an efficient success in extracts of fresh leaves and fruits $(1,000 \mu \mathrm{g} / \mathrm{mL})$ and dried fruits $(2,000 \mu \mathrm{g} / \mathrm{mL})$ of 1 . theezans. The native dried fruit extract of I. paraguariensis also showed greater than $50 \%$ activity in concentration of $1,000 \mu \mathrm{g} / \mathrm{mL}$. All extracts of I. paraguariensis matched to the control $(p<0.01)$ (Table 2).

Table 1 - Variance analysis of the number of Aedes aegypti living larvae exposed to treatments with hydroalcoholic extracts of $I$. paraguariensise and of $I$. theezans under laboratory conditions (temperature $28^{\circ} \mathrm{C}$ and 12 hours photoperiod).

\begin{tabular}{|l|c|c|c|}
\hline Variation cause & Degrees of freedom & Average square & Probability \\
\hline Treatment & 28 & 0.82 & $\mathrm{p}<0.01$ \\
\hline Hours & 3 & 3.93 & $\mathrm{p}<0.01$ \\
\hline Treatments $\mathrm{x}$ hours & 84 & 0.26 & $\mathrm{p}<0.01$ \\
\hline Residue & 232 & 0.04 & \\
\hline Total & 347 & &
\end{tabular}

Coefficient of variation $=6.8 \%$

Table 2 - Treatments, average of $A$. aegypti alive after 72 hours of exposure to treatment with hydroalcoholic extracts of $l$. paraguariensise of $l$. theezans followed by standard error and efficiency percentage in laboratory conditions (temperature $28^{\circ} \mathrm{C}$ and 12 hours' photoperiod). Means followed by capital letters differ by Duncan test $(p<0.01)$.

\section{Treatments}

\section{Control}

1. paraguariensis fresh native fruits $750 \mu \mathrm{g} / \mathrm{mL}$

I. paraguariensis fresh native leaves $1,000 \mu \mathrm{g} / \mathrm{mL}$

I. paraguariensis fresh cultivated leaves $1,000 \mu \mathrm{g} / \mathrm{mL}$

I. paraguariensis fresh cultivated fruits $1,000 \mu \mathrm{g} / \mathrm{mL}$

I. paraguariensis fresh native leaves $2,000 \mu \mathrm{g} / \mathrm{mL}$

I. paraguariensis dry native leaves $1,000 \mu \mathrm{g} / \mathrm{mL}$

I. paraguariensis dry native leaves $2,000 \mu \mathrm{g} / \mathrm{mL}$

I. paraguariensis dry cultivated leaves $2,000 \mu \mathrm{g} / \mathrm{mL}$

I. paraguariensis dry cultivated leaves $1,000 \mu \mathrm{g} / \mathrm{mL}$

I. paraguariensis dry native fruits $1,000 \mu \mathrm{g} / \mathrm{mL}$

1. paraguariensis fresh cultivated fruits $2,000 \mu \mathrm{g} / \mathrm{mL}$

I. paraguariensis fresh cultivated leaves $2,000 \mu \mathrm{g} / \mathrm{mL}$

I. paraguariensis dry cultivated fruits $750 \mu \mathrm{g} / \mathrm{mL}$

I. paraguariensis fresh native fruits $1,000 \mu \mathrm{g} / \mathrm{mL}$

I. paraguariensis dry native fruits $2,000 \mu \mathrm{g} / \mathrm{mL}$

I. theezans freen leaves $750 \mu \mathrm{g} / \mathrm{mL}$

I. paraguariensis fesh native fruits $2,000 \mu \mathrm{g} / \mathrm{mL}$

1. paraguariensis dry cultivated fruits $1,000 \mu \mathrm{g} / \mathrm{mL}$

I. theezans dry fruits $1,000 \mu \mathrm{g} / \mathrm{mL}$

I. theezans fresh fruits $2,000 \mu \mathrm{g} / \mathrm{mL}$

I. theezans fresh leaves $1,000 \mu \mathrm{g} / \mathrm{mL}$

I. theezans fresh fruits $1,000 \mu \mathrm{g} / \mathrm{mL}$

I. theezans dry leaves $750 \mu \mathrm{g} / \mathrm{mL}$

\begin{tabular}{|c|c|}
\hline Alive larvae & $\%$ Efficiency $(\mathbf{7 2} \mathbf{h})$ \\
\hline $20 \pm 0 \mathrm{~A}$ & $0 \%$ \\
\hline $20 \pm 0 \mathrm{~A}$ & $0 \%$ \\
\hline $20 \pm 0 \mathrm{~A}$ & $0 \%$ \\
\hline $20 \pm 0 \mathrm{~A}$ & $0 \%$ \\
$20 \pm 0 \mathrm{~A}$ & $0 \%$ \\
$20 \pm 0 \mathrm{~A}$ & $0 \%$ \\
\hline $20 \pm 0 \mathrm{~A}$ & $0 \%$ \\
\hline $20 \pm 0 \mathrm{~A}$ & $0 \%$ \\
\hline $19.66 \pm 0.08 \mathrm{~A}$ & $0 \%$ \\
\hline $19.33 \pm 0.77 \mathrm{~A}$ & $1.7 \%$ \\
\hline $18.66 \pm 0.11 \mathrm{~A}$ & $3.35 \%$ \\
\hline $18.66 \pm 0.23 \mathrm{~A}$ & $6.7 \%$ \\
\hline $16.03 \pm 0.65 \mathrm{AB}$ & $6.7 \%$ \\
\hline $14.93 \pm 0.57 \mathrm{AB}$ & $19.85 \%$ \\
\hline $13.93 \pm 0.98 \mathrm{AB}$ & $25.35 \%$ \\
\hline $13.85 \pm 0.69 \mathrm{AB}$ & $30.35 \%$ \\
\hline $12.82 \pm 0.84 \mathrm{AB}$ & $30.75 \%$ \\
\hline $9.76 \pm 1.37 \mathrm{AB}$ & $35.9 \%$ \\
\hline $8.78 \pm 1.41 \mathrm{~B}$ & $51.2 \%$ \\
\hline $8.58 \pm 1.43 \mathrm{BC}$ & $56.1 \%$ \\
\hline $6.23 \pm 2.03 \mathrm{CD}$ & $57.1 \%$ \\
\hline $5.64 \pm 1.74 \mathrm{CD}$ & $68.85 \%$ \\
\hline $1.88 \pm 2.36 \mathrm{E}$ & $71.8 \%$ \\
\hline & $90.6 \%$ \\
\hline
\end{tabular}


The most effective larvicidal effect of the extracts was observed after 24 hours of exposure. Although it was observed activity in the period between 0 and 24 hours for the fresh leaf extract of
I. theezans $(1,000 \mu \mathrm{g} / \mathrm{mL})$, the stronger activity of the other was observed in the period between 24 and 48 hours and less intense between 48 and 72 hours (Figure 1 ).

\section{DISCUSSION}

The results showed that the hydroalcoholic extracts of leaves and fruits, both fresh or dry of $I$. theezans showed larvicidal activity at all concentrations tested, and concentrations above $750 \mu \mathrm{g} / \mathrm{mL}$ were the most efficient. The extract of dried leaves of $I$. theezans at a concentration of $750 \mu \mathrm{g} / \mathrm{mL}$ was the most efficient (Table 2). In 72 hours, it showed the efficiency of $90.6 \%$. The fresh fruits extract of this species presented $71.8 \%$ efficiency. The highest activity was observed in the period between 24 and 48 hours of exposure (Figure 1).

Ilex theezans is an early successional species, considered one of the most frequent in Mixed Rain Forest and according to Viani and Vieira (2007) it usually coexists with I. paraguariensis. The I. theezans leaves are mixed in the mate to increase the bitterness, having a higher concentration of saponins. The main biological activities of saponins are related to their active tense, complexing, haemolytic and toxic properties (MAHATO; SARKAR; PODDAR, 1988). The fact that I. theezans had larvicide effectiveness against $A$. aegypti may be related to the presence of a higher concentration of saponins usually used to differentiate species of Ilex. However, they would require additional studies on their composition.

It was noticed that the extracts of $I$. theezans showed the highest efficiency between 24 and 48 hours. After this period, the activity was still observed, although with a reduction in the effect of the extracts on $A$. aegypti larvae. For Garcia (2014), a product is commercially efficient and recommended if it shows lethality inferior to $80 \%$, so that there is a selection of genes causing resistance. One of the treatments reached the parameter of the extract of dried leaves of $I$. theezans $(750 \mu \mathrm{g} / \mathrm{mL})$.

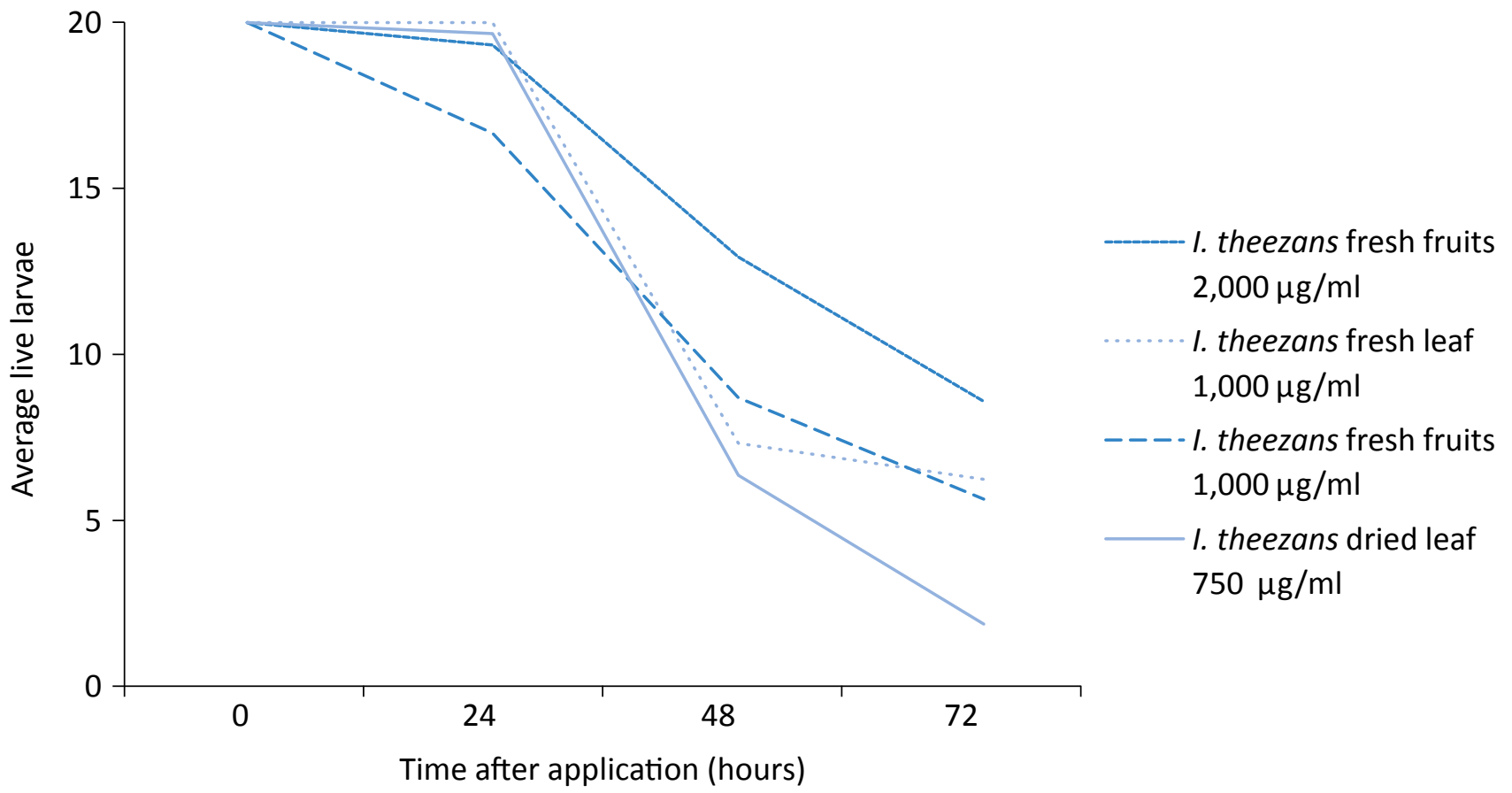

Figure 1 - Survival of $A$. aegypti larvae exposed to different concentrations of $I$. theezans extracts, evaluated every 24 hours under laboratory conditions (temperature $28^{\circ} \mathrm{C}$ and 12 hour photoperiod). 
Fruit and fresh and dry leaves extracts of I. paraguariensis, native and planted, from the concentration of $1,000 \mu \mathrm{g} / \mathrm{mL}$ showed a relatively low larvicide efficiency when compared to extracts of $I$. theezans (Table 2 ). The fact of being native or planted did not result in differences in this study. For more favorable, shaded and with specific microclimatic condition environments, such as intensity and duration of sun radiation, and the predetermined genetic variations (COELHO; MARIATH; SCHENKEL, 2002) and even the presence or absence of endophytic microorganisms (MELO \& AZEVEDO, 1998), differences in the activity of the extracts were expected. Studies regarding the phytochemical composition of yerba mate demonstrated that their compounds may vary in quantitative and qualitative terms, such as the type of crop, climate, agronomic conditions, plant age, methodology analysis and industrial processing (DUTRA, 2009). In the study of Busato et al. (2015), in a bioassay using a hydroalcoholic extract of $I$. paraguariensis leaves, using the drying method in an oven for 48 hours, larvicide efficiency was checked on A. aegypti, with $100 \%$ mortality at a concentration of $2,000 \mu \mathrm{g} / \mathrm{mL}$. Comparing the results of Busato et al. (2015), it is possible to infer that the extracts of the preparation method may have influenced the results for $I$. paraguariensis.

The fresh and dry fruits of I. paraguariensis showed greater activity than the leaves of the same species. The fresh fruits of yerba mate, compared to the leaves, showed higher concentrations of saponins, which are present as a defense against herbivores and other forms of consumption and predation (PAVEl et al., 2007). After ripening, there is a predominance of other nutrients, which facilitate the use and dispersal of seeds, such as sugar, proteins, fats and carbohydrates (RAVEN; EVERT; EICHHORN et al., 1996). Probably these saponins in fresh fruits of I. paraguariensis were lethal to $A$. aegypti larvae. The effect of this saponin in fruits of various families of plants is known to be deleterious to the development of pests of maize monocultures such as Spodoptera frugiperda (Smith, 1797) and Helicoverpa zea caterpillars (Boddie 1850) (DOWD et al., 2011).

The great commercial interest in I. paraguariensis as well as its cultural and gastronomic aspects is due to the presence of xanthine bases. According to Borges et al. (2013), one of the main constituents of yerba mate leaves used for teas are methylxanthines, caffeine, theobromine and theophylline traits.

These results open perspectives in replacement of synthetic insecticides by natural products in the control of $A$. aegypti, by their abundant presence in southern Brazil. These results are promising, creating the possibility for further studies regarding the use of extracts of these plants as larvicides of $A$. aegypti, as an alternative to the synthetic products. For the treatments carried out, the method of extraction and preparation of $I$. paraguariensis extracts proved to be little efficient. One possibility is that not all compounds were released during the process of preparation. For the species I. theezans, the method was efficient, widening the perspective for further studies of this yet little used species.

\section{ACKNOWLEDGMENT}

Research supported (scholarship) by CNPq/PIBITI (Notice 180/Dean/2015) and the Universidade Comunitária da Região de Chapecó - UNOCHAPECÓ.

\section{REFERÊNCIAS}

BARRETO, C. F. Aedes aegypti - Resistência aos inseticidas químicos e as novas alternativas de controle. Revista Eletrônica Faculdade Montes Belos, v. 1, n. 2, p. 62-73, 2005.

BARRETO, M. L.; TEIXEIRA, M. R. Dengue no Brasil: situação epidemiológica e contribuições para uma agenda de pesquisa. Estudos Avançados, v. 22, n. 64, p. 53-72, 2008.

BORGES, A. C. P.; DARTORA, N.; RIL, F. T.; GONÇALVES, I. L.; VALDUGA, A. T. Avaliação do conteúdo de cafeína na oxidação de folhas de llex paraguariensis st. Hil. Revista de Ciência e Tecnologia, v. 15, n. 20, p. 38-43, 2013. 
BRUNHEROTTO, R.; VENDRAMIM, J. D. Bioatividade de Extratos Aquosos de Melia azedarach L. Sobre o Desenvolvimento de Tuta absoluta (Meyrick) (Lepidoptera: Gelechiidae) em Tomateiro. Neotropical Entomology, v. 30, n. 3, p. 455-459, 2001.

BUSATO, M. A.; VITORELLO, J.; LUTINSKI, J. A.; MAGRO, J. D.; SCAPINELLO, J. Potencial larvicida de Melia azedarachL. e Ilex paraguariensis A. St.-Hil. no controle de Aedes aegypti (Linnaeus, 1762) (Diptera: Culicidae). Ciência e Natura, v. 37, n. 2, p. 277-282, 2015.

CALDAS, L. Q. A. Intoxicações exógenas agudas por carbamatos, organofosforados, compostos bipiridílicos e piretróides. Rio de Janeiro: Centro de Controle de Intoxicações de Niterói, 2000. 40p.

CASTALDELLI, A. P. A.; VIEIRA, L. P.; PRZYGODDA, F.; MARTINS, Z. N.; PADOIN, M. J. Efeito da erva mate (Ilexparaguariensis A. St. -Hil.) no comportamento e fisiologia de ratos Wistar. Brazilian Journal of Biosciences, v. 9, n. 4, p. 514-519, 2011.

COELHO, G. C.; MARIATH, J. E. A.; SCHENKEL, E. P. Populational diversity on leaf morphology of Maté (Ilex paraguariensis, A. St.-Hil., Aquifoliaceae), Brazilian Archives of Biology and Technology, v. 45, n. 1, p. 47-51, 2002.

DOWD, P. F.; JOHNSON, E. T.; VERMILLION, K. E.; BERHOW, M. A. \& PALMQUIST, D. E. Coconut leaf bioactivity toward generalist maize insect pests: coconut leaf bioactivity. Entomologia Experimentalis et Aplicata, v. 141, n. 3, p. 208-215, 2011.

DUTRA, F. L. G. Compostos fenólicos e metilxantinas em erva-mate armazenada em sistemas de estacionamento natural e acelerado. 77 f. Dissertação (Mestrado em Tecnologia de Alimentos) - Departamento de Setor de Tecnologia. Universidade Federal do Paraná, Curitiba, 2009.

GARCIA, F. R. M. Zoologia Agrícola: manejo ecológico de pragas. 4. ed. Porto Alegre: Rígel. 2014. 256 p.

GIBERTI, G. C. Ilex en Sudamérica: florística, sistemática y potencialidades con relación a un banco de germoplasma para la yerba mate. In: REUNIÃO TÉCNICA DO CONE SUL SOBRE A ERVA-MATE, 1995, Porto Alegre Anais. Porto Alegre: Universidade Federal do Rio Grande do Sul, 1995. p. 303-312.

GOMES, A. S.; SCIAVICO, C. J. S.; EIRAS, A. E. Periodicidade de oviposição de fêmeas de Aedes aegypti (Linnaeus, 1762) (Diptera: Culicidae) em laboratório e campo. Revista da Sociedade Brasileira de Medicina Tropical, v. 39, p. 327-332, 2006.

GUARDA, C.; LUTINSKI, J. A.; ROMAN-JUNIOR, W. A.; BUSATO, M. A. Atividade larvicida de produtos naturais e avaliação da susceptibilidade ao inseticida Temefós no controle do Aedes aegypti (Diptera: Culicidae). Interciência, v. 41, n. 4, p. 243-247, 2016.

KRICUN, S. D. P. Yerba mate: investigación agronómica en la Republica Argentina. Cerro Azul: INTA, Estación Experimental Agropecuária de Misiones, 1983. 16p.

LORENZI, H.; MATOS, F. J. A. Plantas medicinais do Brasil: nativas e exóticas. São Paulo: Instituto Plantarum de Estudos da Flora, 2002. 512p.

MAHATO, S. B.; SARKAR, S. K.; PODDAR, G. Triterpenoid saponins. Phytochemistry, v. 27, n. 10, p. 3037-3067, 1988.

MELO, I. S.; AZEVEDO, J. L. Controle biológico. Jaguariúna: Embrapa Meio Ambiente, 1998. v. 1.

NEVES, D. P. Parasitologia humana. 12. ed. São Paulo: Atheneu, 2011. 556 p.

PAVEI, C.; GUZATTO, P.; PETROVICK, P.; GOSMANN, G.; GONZÁLEZ-ORTEGA, G. Development and validation of an HPLC method for the characterization and assay of the saponins from Ilex paraguariensis A. St.-Hil (mate) fruits. Journal of Liquid Chromatography and Related Technologies, v. 30, p. 87-95, 2007.

PIOVEZAN-BORGES, A. C.; VALÉRIO-JÚNIOR, C.; GONÇALVES, I. L.; MIELNICZKI-PEREIRA, A. A. \& VALDUGA, A. T. Antioxidant potential of yerba mate (Ilex paraguariensis St. Hil.) extracts in Saccharomyces cerevisae deficient in oxidant defense genes. Brazilian Journal of Biology, v. 76, n. 2, p. 539-544, 2016. 
POWELL, J. R.; TABACHNICK, W. J. History of domestication and spread of Aedes aegypti - a review. Memorias do Instituto Oswaldo Cruz, v. 108, p. 11-17, 2013.

RATES, S. M. K. Metilxantinas. In: SIMÕES, C. M. O.; SCHENKEL, E. P.; GOSMANN, G.; MELLO, J. C. P.; MENTZ, L. A.; PETROVICK, P. R. (Eds.). Farmacognosia: da planta ao medicamento. 5. ed. Porto Alegre: Editora Universidade Federal do Rio Grande do Sul, 2004. p. 885-901.

RAVEN, P. H.; EVERT, R. F.; EICHHORN, S. E. Biologia vegetal. 5. ed. Rio de Janeiro: Guanabara Koogan, 1996. 728 p.

ROSSI, J. C. N.; PROPHIRO, J. S.; MENDES, A. M.; KANIS, L. A.; SILVA, O. S. Efeito larvicida de extratos etanólicos de folhas secas e frutos maduros de Melia azedarach (Meliaceae) sobre Aedes albopictus. Latin American Journal of Pharmacy, v. 26, n. 5 , p. 737-740, 2007.

SANTIAGO, G. M. P.; VIANA, F. A.; PESSOA, O. D. L.; SANTOS, R. P.; POULIQUE, Y. B. M.; ARRIAGA, A. M. C.; ANDRADE-NETO, M.; BRAZ-FILHO, R. Avaliação da atividade larvicida de saponinas triterpênicas isoladas de Pentaclethra macroloba (Willd.) Kuntze (Fabaceae) e Cordia piauhiensis Fresen Boraginaceae sobre Aedes aegypti. Revista Brasileira de Farmacognosia, v. 15, n. 3, p. 187-190, 2005.

SOUZA, M. F. F. Chá mate (Ilex paraguariensis): compostos bioativos e relação com atividade biológica. Dissertação (Mestrado em Nutrição) - Faculdade de Saúde Pública, Universidade de São Paulo, São Paulo, 2009. 147 p.

TAUIL, P. L. Aspectos críticos do controle do dengue no Brasil. Cadernos de Saúde Pública, v. 18, n. 3, p. 867-871, 2002.

VALLADARES, G.; DEFAGO, M. T.; PALACIOS, S. Laboratory evaluation of Melia azedarach (Meliaceae) extracts against the Elm Leaf Beetle (Coleoptera: Chrysomelidae). Journal of Economic Entomology, v. 90, n. 3, p. 747-750, 1997.

VIANI, R. A. G.; VIEIRA, A. O. S. Flora arbórea da bacia do rio Tibagi (Paraná, Brasil): Celastrales sensu Cronquist. Acta Botanica Brasilica, v. 21, n. 2, p. 457-472, 2007. 